\title{
Women's political equality: theoretical approaches to affirmative action
}

\author{
Denisse M. Lazo González*
}

\author{
Nivel: Comunicado \\ Fecha de recepción: 20 de julio de 2011 \\ Fecha de aprobación: 12 de agosto de 2011
}

\begin{abstract}
The following essay presents an overview of theoretically based issues around the debate on women's political representation and participation, having as a central strand the appropriateness of affirmative action strategies. It is built from the justifications that support the need for better ways of representing disadvantaged groups in general and women in particular as a requirement for democracy and social justice. The essay debates affirmative action and some false assumptions around it, arguing for gender quotas as the strongest mechanism to achieve a definite inclusion of women into politics.
\end{abstract}

Key words: Gender Politics, Affirmative Action, Representation.

\section{Resumen}

El siguiente ensayo presenta una mirada a algunos de los enfoques teóricos que dictan el debate de la participación y representación política de las mujeres, teniendo como hilo conductor la pertinencia de las estrategias de acción afirmativa. Se desarrolla a partir de los razonamientos que apoyan la necesidad de contar con mejores métodos de representación de grupos en desventaja en general y de las mujeres en particular como requerimiento para la democracia y la justicia social. El ensayo debate sobre la acción afirmativa y algunos de los supuestos que rodean este concepto y presenta a las cuotas de género como el mecanismo más fuerte para alcanzar una inclusión permanente de las mujeres en la política.

Palabras Claves: Género y Política, Acción Afirmativa, Representación.

* Master of Studies in Women's Studies, University of Oxford, UK, Licenciada en Lengua y Literatura Inglesas, Universidad de Chile. Universidad Católica Silva Henríquez, Santiago, Chile. dlazo@ucsh.cl 


\section{Introduction}

The practice of politics has been historically a male concern. It has defined its scope from the traditional division between the public and the private spheres; public male issues and private women's issues related to household and family. This pattern has kept women away from power and decision-making and prevents them from getting involved in the political and public scene. Such a pattern has also shaped structural and institutional barriers for women's political participation and a political culture with hostile attitudes towards women as political leaders and decision-makers. Justifications and mechanisms to achieve women's political equality, representation, and participation have been built from feminist critique of abstract concepts and undifferentiated norms based on the masculine principles of neutrality and equal treatment to all individuals. These critiques have raised the question of representation and affirmative action mechanisms in the search for fairer levels of political participation. The debate about affirmative action is then constructed around the deficiencies of liberal individualism, the importance of paying attention and giving space to difference, justifications and defence of affirmative action, and the best mechanisms to reach fairer election patterns.

In its ancient and modern phase, democratic theory and politics was supposed to be gender neutral overlooking gender-sexual difference. However, such neutrality indeed had gendered implications. The sexual division of roles based on biological characteristics meant discrimination against women and social barriers supporting gender inequalities to participate in the public scene. The "nature" of women pushed them to the private sphere, since family matters were incompatible with the responsibilities of a public career. As Anne Phillips explains it, 'for Aristotle, this meant women had no place in politics, for their "nature" was such that it fitted them only for the inferior virtues of the private sphere' (Phillips, 1991: 29). The historical concept of democracy 
was not inclusive let alone gender neutral; the Ancient Greek concept, excluded women, slaves, and foreigners, and the democratic concepts of modern societies in the nineteenth century were only experienced by men with certain social and economic status. Such concepts of democracy excluded women who lived democracy through their men, husbands, fathers, brothers, or sons. Under the shadow of their men, women were not considered citizens; as Phillips states, 'women had no need of a voice of their own, for they had fathers and husbands to speak for their interests and it made no sense to think of women apart' (Ibid.: 25).

The ancient and modern conception of democracy is the main theoretical structure of current democratic systems and the source that may explain how difficult it has been for women to enter the political arena, to get involved in politics, and to think of them confidently as political subjects affected by and interested in the political machinery. This image still reflects strongly the socially assumed women's lack of interest in political affairs. In the patriarchal construction of politics, women lack the necessary conditions to engage in political life; as Carole Pateman puts it in her The disorder of women, women cannot transcend their nature so linked to their bodies and sexual passions, lacking the political morality that men have when being able to use their reason and sublimate their passions (Pateman, 1989:4). In current democratic regimes which mainly derive from the liberal trend, women are not an active part of the political practice nor fully hold a visible position within the theory. Liberal theory accepts the idea that some rights are inviolable for they exist in a private sphere, those are marriage, family, household, and childcare, where the State cannot interfere. At this point, gender politics and its gender-based approaches has incorporated new levels of analysis, dimensions, and issues that challenge the traditional view of the political theory and of key concepts related to democracy. It uncovered the supposed gender neutrality of political and democratic concepts, and it has established new patterns for researching political theory and measuring political participation: behind the supposed 
women's lack of interest in politics there must be key issues preventing women from enjoying free, full, and equal involvement in politics (Phillips, 1991: 63). Following Phillips, what seemed to be an absence is, in the light of closer analysis, a powerful masculine pattern. Political theorists have defined this pattern as an abstract model away from 'the pettiness of everyday, or the accidents of gender and class, but in doing so they have taken one sex alone as their standard, forcing the other one to conform or be damned' (Ibid.: 5). The "individual", fundamental to the political theory, is not gender neutral. Individuals are sexually indifferent only if they are disembodied (Pateman, 1989: 3) and it is a misreading to consider the terms "men" and "individual" as generic or universal including both men and women. As Pateman explains it, the classic contract theorists argued that freedom and equality were birthrights for men only, since men are born free and equal; they constructed sexual difference as a political difference, a difference based on men's natural freedom and women's natural subjection (Ibid.: 5). Identifying politics with the public sphere and public activities denies the pertinence of gender and defines politics and democracy as male-centred (Phillips, 1991: 6). Women continue to be forced to respect the family-private contract, which is an imposed social and moral obligation.

In the following essay, Part I presents some theoretical arguments from the literature regarding the representation of groups and their right to civic participation in a plural society that intends to be more equal, just, and democratic. Part II debates on the assumed discriminatory nature of affirmative action and the inaccuracy of merit as a judgement criterion of preparedness for a proper political performance. Part III presents the most influential barriers that hinder women's political participation and argues for quotas as a necessary mechanism to overcome women's underrepresentation and political disempowerment. The concluding part presents some final thoughts about affirmative action, women's political representation, and women's political equality as a primary goal to achieve in the process of 
a cultural change towards the perception of women as political leaders.

\section{Representation as a requirement for democracy and social justice}

There is no direct relationship between people who get elected as representatives and decision-makers and the real composition of the population they are meant to represent. This mismatch is risky for any attempt to attain democracy. But, which are the grounds to state that representation is a goal to achieve and to support affirmative action to reach better ways of representation? Different theoretical approaches have been developed to support group representation and civic participation, and from this to argue for equality in the way in which women are represented and encouraged to participate in politics. In the context of societies that have various cultural forms and are composed of different groups, justifications supporting the political representation of difference become a fundamental requirement for social justice. Nowadays, in liberal democratic systems there is equal civic status between men and women and among citizens belonging to different cultural backgrounds, however, political representation and participation continue to be a matter of hegemonic identities. The universalising principles and approaches of liberal democracy contribute to create biased notions of equality, participation, and representation.

Liberal democratic theory has two main exclusionary aspects. First, as it bases citizenship on individualism, it treats citizens as individuals who compete for their own interests executing self capacity. Thus, it does not pay much attention to citizens' political participation within a community, to group differences and relationships, and to the requirements for such a competition. Second, it maintains the division between the private and political or public spheres, including as part of its scope only the latter. The exclusion of domestic life -which has been traditionally thought 
to be the natural realm of women-, primarily means a division between women and men, and the social roles assigned to them (Pateman, 1989). Liberal individualism aspires to a society in which group membership or physical attributes do not interfere with people's social position. Specific identities should be kept as a private concern, since the public arena assumes every person as morally and politically equal. Though the liberal conception of free individuals has contributed to the idea that all persons are born free and equal and that the principles of justice should not favour any group or particular conception of life or well being, it does not encourage participation, it devaluates civic action and common concerns, and it does not account for group specificities and difference, conceiving it as otherness (Young, 1995). Carole Pateman points out that liberal individualism promised equality between women and men as naturally free individuals, but at the same time the socio-economic liberal patterns for development support the idea of a natural subordination of wives to husbands, which has left them outside the scope of democratic and liberal theories (Pateman, 1989). Women do not have the opportunity to develop capacities or to learn what to be a citizen is, because spaces where these values can be practiced such as the workplace or the public sphere are denied to them; 'women will not be able to learn what their interests are without experience outside domestic life' (Ibid. 217) because 'a patriarchal family with the despotic husband at its head is no basis for democratic citizenship (Ibid.)'.

Though in relation to political communities on a larger scale, Chantal Mouffe emphasises the significance of civic action and common concerns in a political community as not necessarily opposed to the rights of an individual so prominent within the liberal tradition. She proposes an articulation between the rights of an individual and citizens' political participation, in what she calls the search for a radical plural democracy. This idea considers that there is no dichotomy between the rights of an individual and participation in a political community. Mouffe argues for a 
political community that aggregates individual freedom and civic participation, for 'what we share and what makes us fellow citizens in a liberal democratic regime is not a substantive idea of the good but a set of political principles specific to such a tradition: the principles of freedom and equality for all' (Mouffe, 1993: 65). For her, citizenship is not just a legal status, but a form of political identification as individuals are part of a community and culture. It is not given but constructed, and although political association does not imply a common good, it does imply the idea of commonality, of an ethico-political bond and linkage among its participants which allows us to think of it as a political community. The political community is built upon the idea of a common bond or public concern, not a common good; it leaves space for individual liberty and pluralism, and does not eliminate difference (Ibid.: 65-68). According to Mouffe, this argument is in favour of a common political identity, a collective identification guided by the principles of liberty and equality; it takes into account different social relations and subject positions like gender, class, ethnicity, and sexual orientation, for the social agent is not a unitary subject, but an articulation of different subject positions (Ibid.: 85).

For Seyla Benhabib, legitimation of power should be through a process of a public dialogue. A dialogic or discourse model of legitimacy is desirable because it is a reflexive one; it challenges existing liberal forms of power relations that damage the interests of those groups that have not been traditional actors in the public space. She sees no limits upon the content of the public conversation; each participant has the same right to initiate or be part of the conversation, and to express wishes and feelings. In this situation of dialogue, speakers must feel free to thematise and to articulate opinions and positions (Benhabib, 1989: 143150), for power is not just a social resource, but it implies sociocultural interpretations and communication, 'public dialogue is not external to but constitutive of power relations' (Ibid.: 150). In a rather similar direction, Iris Young states that the democratic 
public should provide mechanisms for recognition and representation of the different voices and perspectives that are oppressed or disadvantaged (Young, 1990: 184), which implies participation of different groups in a society. She criticises the idea of assimilation which she defines as liberation by the elimination of group difference, an ideal of justice that defines liberation as the transcendence of group difference and that does not allow groups to speak for themselves. Instead of equal treatment as a primary principle of justice, a positive self definition of group difference is more liberatory (Ibid.: 157).

Following Young, experimental differences must be acknowledged. She argues for a group differentiated politics, which is fundamental to mobilisation and programmes to undermine oppression and to encourage social justice. Conceiving difference as otherness and exclusion essentialises group natures; it usually produces dichotomies or mutually exclusive groups as categorically opposed entities, with fixed definitions of what is part of the group and what is excluded from it. Traditionally, two ideals have been developed to overcome oppression by exclusion, those are assimilation and separation. The first ideal -highly supported by liberal individualism- states that people should be considered as individuals evaluated on their own merits and not as belonging to any specific group. However, by rejecting group difference, this ideal essentialises the conception of group identity and it does not correspond to real experience. In practice, according to Young, group affinities and cultural life are a source of friendship and solidarity; thus, this ideal presumes a conception of the individual self prior to any social context (Young, 1995). The second ideal is separatism, which states that the best option for oppressed groups is freedom and development by separating from the dominant group, aspiring to political and territorial sovereignty. However, dispersed populations make this ideal highly improbable. According to Young, though the separatist model helps create cultural identification, autonomy, and political solidarity, it also creates a sense of difference as otherness and does 
not acknowledge differences within groups. Both the assimilationist and separatist ideals have been constructed around fixed group identities, definitions of groups as "Other", and do not account for the reality of groups which experience interfusion and interdependence in practice (Ibid.: 158-164). Young proposes another conception of difference based on a relational logic.

Groups are constituted in relation to one another; they not only interact vividly among each other, but mutually excluded group identities in fact depend on each other. They are defined by reference to the categories that are opposed to them. Even the most intrinsic meanings for identification are given in relation -opposition or comparison- to the characteristics attributed to other groups. Their differences are contextual, without another group to be compared with there is no difference or particular identification. A notion of group difference based on otherness limits a proper understanding of the various interactions groups perform in reality and the interdependence of their categorisations. It denies the heterogeneity of social difference, understood as variation and contextually experienced relations. It denies group internal differences, that is, differences among people who understand themselves as belonging to the same group, and it reduces the members of a group to a set of common attributes (Ibid.: 159).

Difference is not otherness, but variation and heterogeneity, 'group identity is not a set of objective facts, but the product of experienced meanings' (Ibid. 161). Young argues for a social and political ideal of togetherness in difference, based on a relational view of group identity, on the idea that a social group is specifically defined as such as the result of social interaction with other groups. This view is necessary to overcome oppression and to promote group proper representation and participation, as it respects group cultural specificities and their own voices. This conception is also more appropriate to account for the contemporary needs for interaction among groups and situa- 
tions of social injustice and conflict. It leads to Young's ideal for a heterogeneous public, a public where the different groups effectively communicate among each other. In this ideal, groups move within social processes that encourage their political interaction, promote mutual recognition, and social justice; for Young, 'social policy should attend to rather than be blind to group difference in awarding benefits or burdens, in order to remedy group based inequality or meet group specific needs' (Ibid.: 165).

Global democracy should be seen as an interaction of self determining peoples who understand their obligation to listen to outsiders affected by their decisions. Conflict resolution needs to be carried out through institutionally settled procedures providing proper representation for different social actors. Inclusive democracy recognises the importance of affinities among groups, enabling participation and voice for all those affected by problems or their solutions. Democratic processes should be based on communicative relations between social sectors and representative bodies responding to the structural differentiation of society (Young, 2002: 9-10). Young states that political representation is better understood as a 'process involving a mediated relation of constituents to one another and to a representative' (Ibid.: 127) rather than as a relation of identity and substitution. Representation is a process taking place over time and it moves between arguments of authorisation and accountability. There is an undeniable difference or separation between the representatives and the constituents that must be acknowledged. The representative function of speaking for does not mean an identifying requirement that the representative speaks as the constituents would. However, though representatives are separate from the constituents, they are also connected to them in different ways. This is the reason why representation systems many times fail in their democratic aim; it is easy to initially establish relations between representatives and those to be represented, what is difficult is to maintain them; representatives usually lose connection with the constituents (Ibid.: 127-129). 
Young's politics of difference considers that equality -defined as participation and inclusion of all groups- sometimes requires different treatment for oppressed or disadvantaged groups, so social policy should sometimes accord special treatment to groups. Though the idea of elimination of group differences has contributed to shape the notion of the equal moral worth of all persons, group difference can certainly be positive. Self organisation and positive group cultural identity are better tools to achieve power and participation; enjoying the benefits of citizenship and a full participation in society do not mean linguistic, cultural, or gender assimilation. Equality as ignoring group difference has as consequences that the social standards are already set by the privileged groups, they ignore their own specificities, and think themselves as "the humanity"; this encourages internal devaluation in the non-privileged groups. On the contrary, the politics of difference or democratic cultural pluralism contributes to four main good practices in society, i) it relativises the dominant culture; ii) it promotes group solidarity against the individualism of liberal humanity; iii) it provides a standpoint from which to criticise prevailing institutions and norms; and iv) it entails self organisation and group autonomy (Young, 1990: 158-167).

Though the politics of difference aims to create the necessary spaces for political inclusion and participation, and it presents a theoretical contribution to decentralise processes that have been historically kept in certain elites, Young's idea of democratic cultural pluralism assumes a harmonious functioning of social groups in current contexts of liberal competitive social systems. In this view, society does not eliminate group difference and there is equality among socially and culturally different groups because there are mutual respect and solidarity among them (Ibid.: 163). Groups are presented as resolving their conflicts through solidarity and support, and many times as being a source of succour with no or minimal internal confrontation, disagreement, or individual competition. As Young explains it, group differing perspectives are usually compatible and enrich everyone's un- 
derstanding in a conflict if they are expressed, 'moreover, group representation would not necessarily increase such conflict and might decrease it. If their differences bring group into conflicts, a just society should bring such differences into the open for discussion' (Ibid.: 189). This optimistic ideal for a model of relationships and conflict resolution supposes a coherent and harmonious self organisation resulting in participation and bringing high impact on the execution of power and decision-making. It has a greater impact if groups have, as Young suggests, a veto power on decisions that may concern them, but it does not say much about the mechanism through which this kind of representation can be reached in practice.

For Anne Phillips, there are practical problems on the way such an organisation accounts for representation. In relation to power over decisions, the precise mechanism of accountability and the exact degree of representation are very important. For instance, if the veto power is exercised through meetings where the group discusses, argues, and agrees its position in order to influence policy making, how representative will those meetings be?, given that these meetings may only attract a minority. If the veto power is exercised through a ballot of all members of the group, what is to guarantee that they are voting "as a group", that they are voting based on their experience and interests as a group? She argues that this is very difficult in practice, because 'none of the groups we might think of is homogenous, and each will contain within itself a wide variety of competing views' (Phillips, 1991: 65-78). For Phillips, search for political equality, and not a better representation of the different groups of a society, is the argument to support affirmative action strategies like quotas which guarantee women's inclusion in the political arena. Women are not a homogenous group and do not speak with a single voice. Representatives cannot be said to act as a group or represent women as a group, for there are ideological and not biological interests involved. As it is highly improbable that representative democracy by itself produces a perfect reflection of the society, changes 
should take place at the institutional level. A better group organisation is a contribution to participation, but in the case of women, only group organisation is not enough; formal and legal mechanisms are needed. In current unequal models of society, though group organisation can in principle encourage participation, it may produce obscure results, since those with more individual resources will continue to monopolise the group-based resources (Phillips, 1995: 289). The necessary capacities, training and connections traditionally required for the political practice will continue to be kept in the hands of those with greater resources. Without specific policies and institutional mechanisms for political parity, political competition will continue to be unfair.

\section{Affirmative action: discrimination and merit}

Affirmative action mechanisms designed to increase and guarantee the participation of women or minority groups in politics and decision-making have been highly debated, especially in relation to an intrinsically discriminatory nature these mechanisms may imply. This discriminatory nature is supposed to lead to a forced re-distribution of offices under unfair conditions. Merit and the assumption that all individuals should be treated as equal and not as conditioned by their membership to any group are the criteria to justify such an argument. This follows from the liberal principle that racial or group classifications and distinctions of race are inherently unjust and that every person has the right to opportunities according to his or her abilities (Dworkin, 1977). Affirmative action mechanisms such as quotas are seen just as another way of discrimination for the benefit of a few.

In the debate on affirmative action as intrinsically discriminatory, Ronald Dworkin is an important referent as the classical liberal defence of affirmative action. Dworkin presents a clear defence of affirmative action programmes through the analysis of the Bakke case which produced an important debate in America in the late 1970s. This case refers to the argument of Allan Bakke 
v. The Regents of the University of California which had an affirmative action mechanism to increase the number of black and other minority students at the medical school, that is to say, for race to count affirmatively. Allan Bakke, white, was not admitted and he sued arguing that if this affirmative action mechanism did not exist he would have been offered a place at the medical school, because his exam scores were the appropriate to be considered. He claimed that this affirmative action programme was against his constitutional right; the California Supreme Court agreed. Ronald Dworkin argues that affirmative action programmes have been wrongly thought as aimed to achieve a racially conscious society divided into different groups, each one entitled to resources and opportunities. Actually, he points out, the American society is already a racially conscious society as a consequence of a history of slavery, repression, and prejudice, and members of a specific racial group do not choose to belong to that group, society makes the classification for them. Affirmative action mechanisms use racially explicit criteria to meet both an immediate goal and a long-term one. The immediate goal is to increase the number of underrepresented groups in power, and the long-term one is to reduce the degree to which society is already a racially conscious one. For him, affirmative action mechanisms rest on judgements of social theory as well as on a calculation of strategy. On the first, societies will continue to be damaged by racial divisions if the most important positions are kept in the hands of the white hegemonic ones, while others remain excluded from the elites. On the second, increasing the representation of those excluded will reduce frustration, injustice, and racial self consciousness while encouraging a better group internal valuation. Increasing the number of people from minority and disadvantaged groups will decrease the degree to which whites think of them as a race or a group rather than as people, and will create different kinds of models, because racism implies that the success of white people means nothing to those belonging to other different groups (Dworkin, 1985). 
It is frequently said that in a pluralistic society, group membership should not influence exclusion or inclusion from benefits, since people have the right to be judged on their merit, that it should be merit the criterion for distribution of benefits and power, not any particular membership. However, Dworkin argues emphatically that that is unrealistic, since historical injustices and social reality show us that group membership does determine inclusion and exclusion from benefits and power. It is a misunderstanding to assume that affirmative action mechanisms are to produce or encourage racial, ethnic, or group divisions within societies; they are rather strong measures because weaker ones would fail to achieve societies without such a determinant racial consciousness that so much defines people's destiny and possibilities (Ibid.). Attempts to overcome the negative results of racial consciousness by neutral means have not succeeded, 'we are therefore obliged to look upon the arguments for affirmative action with sympathy and an open mind' (Ibid.: 295); moreover, 'we must not forbid them in the name of some mindless maxim, like the maxim that it cannot be right to fight fire with fire, or that the end cannot justify the means' (Ibid). Affirmative action programmes which goal is to attack a national problem have more benefits that potential costs; they are a calculation about the socially most beneficial use of resources (lbid). The right of individuals to be treated as equals means that their potential loss should be a concern, but that does not mean that such loss may nevertheless be outweighed by the benefit of a community as a whole (Dworkin, 1977).

Merit is usually the paramount criterion when justifying the election of representatives and authorities; therefore, from such a perspective, affirmative action is seen as an imposed policy that discriminates to create spaces for those who do not necessarily deserve it. Those winning elections are supposedly the ones with the necessary requirements and merits as judged by the population via the use of vote in free and democratic elections. Under an idealised democratic context of civic participation, the population 
elects among a group of candidates proposed to them those with the higher qualifications to be responsible of representing them or their interests. Another kind of approach to election systems would damage their democratic spirit and would possibly allow female candidates to get political positions without much merit, for they probably would not have been elected if this affirmative action mechanism did not exist. Affirmative action then happens to be against the principle of non-discrimination and the liberal belief that all people must be treated as equal individuals and not as belonging to any specific group. This then unfair way of electing authorities given by affirmative action mechanisms, though aimed at repairing injustice, would create a negative perception around the election of women who are seen as incapable of getting a political position without any help from a re-distribution of offices. For Young, this is the wrong perspective to analyse affirmative action, for merit is a myth and re-distribution is not the proper justification to support affirmative action as a mechanism against injustice.

Following Young, injustice has to be defined in terms of oppression and domination such as racism and sexism, not distribution. The affirmative action debate is too much centred on issues related to distribution, defining gender and racial injustice merely under the distributive patterns of who gain more offices or important political positions. The problem with this view is that it does not question the institutional organisation of decision-making powers. Arguments targeted at viewing affirmative action as policies that counteract current biases and prejudices of the decision-making power are more appropriate rather than the traditional view of affirmative action policies as compensation for a history of discrimination (Young, 1990: 193194). On the dilemma of affirmative action policies as violating the moral principle of non-discrimination, Young argues that they do discriminate in the sense that they are "conscious preferential practices". She suggests that the dilemma disappears if defenders of affirmative action stop assuming that non-dis- 
crimination is the leading principle behind their arguments for justice, for racial and sexual injustices do not come under this concept. Discrimination is not the primary wrong groups suffer; it is oppression the most significant concept behind grouprelated injustices. Though discriminatory policies may cause and reinforce oppression, oppression also involves practices and structures beyond the mere awarding or distribution of benefits, and allowing the principle of equal treatment or nondiscrimination to be the absolute one means an ideal of equality as sameness. Affirmative action is not an exception to the principle of discrimination, but it is 'one of many group-conscious policies instrumental in undermining oppression' (Ibid.: 195). Moreover, identifying injustices suffered by groups with discrimination puts on the victim the responsibility of proving the harm that has been done. Therefore, as the concept of discrimination is focused on the individual, it fails to acknowledge and question the structural and institutional working of oppression (Ibid.: 196-197).

Young argues that affirmative action based on the distributive paradigm may have some success in redistributing positions; it implies, in principle, that candidates should be highly qualified in a competition where the best one wins. However, there are deeper levels of analysis that show that the criterion of merit in the distribution of positions of power and decision-making does not result in a meritocracy. There are structures of privilege and oppression not only behind the assignment of important positions, but obscuring the whole process, from the mere acquisition of qualifications to the presentation of candidates to an electorate, or the allocation of posts. Those assigned to an office are not necessarily those with best qualifications or those who won the fairer race, for there are structures of privilege, oppression, and discrimination making the process unfair which need to be altered. This requires changes in the patterns of social, racial, class, and gender stratification; changes in the structures of our societies and in the whole process of power allocation, and makes the 
idea of an objective, fair, and unbiased merit criterion as a version of impartiality, a myth (Ibid.: 199-202).

The myth of merit as the criterion for election and the idea that women lack such merit if their political participation is encouraged by any affirmative action presume an equal and fair starting point between women and men in the political race. If merit is the criterion for the electorate to prefer men, and if women with the necessary merit will anyway gain their election without any help from affirmative action mechanisms as men do, then why it does not happen like that? Are there not as many meritorious women as men? Women and men historically have not had an equal space in politics -from theory to practiceand have not been provided with equal chances to participate in it. Different social, cultural, and institutional barriers prevent women from engaging in any public role and many times even from acquiring any qualification that allow them to be evaluated as potential candidates for an office. Women do not enjoy an equal position even at the starting point of the political race, for they many times do not even have time to get involved in a third role beyond household and work. This sexist and elitist functioning of privilege around merit acquisition makes merit unfair and devalues it as a judgement of preparedness to the responsibilities of politics. Merit and qualification as principles to evaluate those who should get elected, or those who should not, put women aside, and does so under the disguise of lack of preparedness.

According to Young, criteria of evaluation are shaped by cultural conceptions and often will not be neutral. They carry assumptions about ways of life, styles of behaviour, and values on the culturally and socially assigned roles to people; such implicit values reflect the experiences and requirements of the privileged ones that design and implement such criteria. Moreover, as a misleading idea of impartiality is assumed by evaluators, particularities are usually discarded as are group difference and values away from the standard. The idea of impartial evaluations le- 
gitimates hierarchies and privileges hegemonic identities (Ibid.: 205-210).

\section{Barriers for women's political participation and mechanisms for equal participation}

Since women are not "a group" but more than half of the world population, demands for fairer political representation seem to be quite logical. However, women continue to be underrepresented at all levels of political practice. Though women make up half of the population and some of them are in political offices, they rarely occupy positions of real power and decision-making, they tend to be placed in positions with less probabilities of being elected or in positions with less power. The low level of growth of women's political participation predicts that they will achieve political parity with men at the turn of the twenty second century (Norris, 2006: 3).

Barriers for women's political participation come from various angles. One of the most influential is political culture, which includes the view of the political tradition as a male concern and the attitudes towards women as leaders or decision-makers. In developing societies, for women it is difficult to engage in political affairs because they are usually disadvantaged by issues like lower levels of education, poor childcare, poverty, poor health systems, and less possibilities of combining productive and reproductive tasks. However, socioeconomic development is not the only condition for women to acquire political power. Women are underrepresented not only in developing countries but also in developed ones with higher levels of socioeconomic development, of democratisation, and with a higher percentage of women who are part of the economically active population. Political culture is a highly important factor as it influences the way in which women see themselves as potential politicians or candidates, the way they evaluate a possible political career, as 
well as the way in which they come to be evaluated as potential candidates (Inglehart and Norris, 2001: 126-140).

In an attempt to introduce a new measure of the significance of ideology for women's political participation, in 2003 Sheri Kunovich and Pamela Paxton carried out a study that analysed the main explanations for women's political underrepresentation. This study attempted to provide a precise measure that confirmed that ideology in fact predicted differences in women's political representation. It presented three significant explanations for women's low political participation; structural, political, and ideological explanations. Structural explanations have to do with the pool of available women, political explanation with how open is the political system to women, and ideological explanations focus on the impressions of women in politics, and how they are seen as leaders or candidates. Despite the fact that mostly the first two types of explanations have been supported statistically, for Kunovich and Paxton ideology is even a more influential barrier to women's political participation which needs and can be measured more precisely (Kunovich and Paxton, 2003: 87-113).

Structural and political barriers for women's political participation are given mainly by two factors, the "supply" of female candidates and the "demand" for female candidates. The former is related to structural factors such as level of education, work opportunities, and types of professions. The latter has to do with institutional differences in political systems; the organisation of the political system may create or not certain "demands" for women irrespectively of the "supply" available. The clearer examples are political parties and type of electoral system which may encourage or decrease the participation of women in politics and decision-making. There are also other political variables such as the degree of democracy a country has achieved, the influence of left-oriented parties that are usually more sympathetic to the idea of women as politicians and leaders, and affirmative action mechanisms such as quotas at national or party level that 
increase in a direct way the number of women candidates and of women actually elected for political offices (Ibid.: 89-90).

Nonetheless, Kunovich and Paxton highlight the ideological explanations for women's political underrepresentation and the possibility of measuring them. Historically, they argue, the presumed women's non-rational nature or ability to make rational decisions has been the primary justification to exclude them from politics. Nowadays, these ideological barriers include ideas about the roles women must satisfy in a society, the position they should occupy in it, and the ability of women to perform a proper role in politics. These cultural norms are so strongly inherited in public opinion that they can inhibit women's interest in politics and the will of the population to elect them. Different variables allow measurement of ideology, such as the ratification of the United Nations Convention on the Elimination of All Forms of Discrimination against Women (CEDAW), the presence of women's movements, and the presence of abortion rights among others (Ibid.: 92). But, Kunovich and Paxton looked for a more direct measure of attitudes that concluded that more egalitarian attitudes are more likely to favour the election of women candidates. In their study they aggregated individual responses to questions about women's place in politics, education, and the labour force. This enabled them to measure a national gender ideology in order to predict women's political participation and to establish 'a national "climate" that may be more or less hospitable to women in politics' (Ibid.: 93). The results they obtained confirmed that an important barrier to overcome is the ideological one including religion. They found that when negative attitudes towards women in political offices increased, the percentage of women in them decreased. These ideological beliefs influence both the supply of and the demand for women. On the first one, ideology influences how women see themselves as potential politicians or leaders, independently of their level of education, socio-economic status, or participation in the labour force. On the second one, ideology influences the will of the population to accept women as within 
their political preferences, as their elected politicians or leaders; and it influences the will of parties to support and work for female candidates, since parties' decisions are usually influenced by their perceptions of the preferences of the electorate (Ibid.: 99-103).

Kunovich and Paxton's results also confirmed that the type of electoral system affects the number of women in national legislature, and concluded that a change in cultural and social values attributed to the idea of women in politics would affect positively the number of women in positions of political power and decision-making. However, though changing social values and perceptions towards women as political leaders is a desirable goal, it is also a long-term one that implies public policies aimed at such a change in all the different sectors of the State. Affirmative action and gender quotas at national level targeted at the elimination of institutional barriers for women's political participation are a primary stage within this long-term and multisectorial process.

There are institutional barriers for women's political participation that need to be corrected. Among them, the type of electoral system and gender quotas are highly important and can reduce or encourage the possibilities of women to participate in politics. According to Norris, though cultural, religious, and socio-economic factors influence women's low participation in politics and underrepresentation, the type of electoral system has a big impact on their probabilities for election. Chances for the election of women tend to increase under party list proportional representation (PR) than under majoritarian electoral systems or combined systems both in countries with established democracies as well as in developing societies. In proportional electoral systems the district magnitude is a central factor, and those with large multimember constituencies are usually more favourable to the election of women (Norris, 2006). Norris argues that women benefit from PR due to three main consequences, i) party vote maximising strategies; ii) patterns of incumbency turnover; and 
iii) implementation of positive action strategies. Under proportional systems, multimember districts encourage parties or coalitions to propose and include attractive candidates that represent the population, or candidates the population feel identified with. If districts are large, the list of candidates will also be long and parties can manage to propose a socially "balanced" list; excluding major social sectors like women or minorities could be judged as discrimination by the electorate, which would risk the chances of being elected. This creates incentives for parties to maximise their possibilities of being voted for and to value the inclusion of different social sectors. On the contrary, majoritarian systems, especially those with single member districts, create minimal incentive and the party or coalition tends to support the candidate that increases their chances. This candidate is usually the default option traditionally associated to males who have historically had the resources and social permission to be dedicated to politics. In this sense, rates of incumbency turnover also have influence. One important barrier for women candidates is the constant re-election of previous candidates due to advantages like familiarity, name recognition, resources, connections, and publicity. According to Norris, in single member districts, the key challenge for women is not becoming a candidate, but contesting a winnable seat, while in PR systems it is being ranked at the top of party lists. Anyway, PR tends to have more space for diversity and facilitate the implementation of affirmative action strategies aimed at including candidates from different sectors and backgrounds. But, changing the electoral systems is not a sufficient condition either (Ibid.). There is scope to incorporate more institutional mechanisms to open spaces for women and to enhance their chances to be elected.

Norris highlights three major institutional mechanisms to achieve gender political parity, statutory gender quotas, reserved seats, and voluntary party quotas. Statutory gender quotas are decreed by law and they are applied to all parties involved in an election. As they are a national legislation, they also can include 
some penalties for those parties that do not meet the percentage of female candidates established by the law. Reserved seats for women can be open to competition with women candidates only; their advantage is that they guarantee a minimum number of women in office through spaces especially created or reserved for them. However they are weak in the sense that, since they do not imply election through public vote, they do not encourage women's electoral competition. Thus, they do not give women equal status as their counterparts elected via public vote and they do not necessarily guarantee their independent decisionmaking power, for they have been appointed by other authority. This sidelines women's political leadership. Finally, voluntary party quotas are implemented, controlled, and monitored by each political party. Parties decide the percentage of women they are willing to support, the type of election in which they are applying the quota (national government, parliamentary elections, local government, or internal elections), and they also decide to apply or not potential sanctions when the quota is not satisfied via internal party regulations. Therefore, though voluntary party quotas are a good practice and show some will for women's political equality, they remain under parties' will, interests, and benevolence. On the contrary, legal policies of statutory quotas are implemented by law and are aimed to rule all parties. Nevertheless, the effectiveness of statutory gender quotas will depend on their design, on factors such as how they are put into practice, the level of gender quota specified by the law, if they regulate all types of elections at all levels, whether the law also regulates the rank order of female candidates, the district magnitude, if the party lists are open or closed, and whether the law establishes or not penalties -and what kind of sanctions- for parties that do not comply with the quota and its requirements (Ibid.: 11-15).

Affirmative action mechanisms have a positive and direct effect on the inclusion of women into the political arena, especially if they take the form of legal gender quotas at national level. These need to specify not only the percentage of women to be 
incorporated in party or coalition lists, but the rank where female candidates are going to be placed needs to be one with clear options to win. Furthermore, if these mechanisms do not explicit sanctions to be applied when political parties or coalitions do not meet them, even these gender statutory quotas will not satisfy their primary objective. This objective is to provide legal paths that encourage and enable women to fully engage in politics and to think of political leadership as a possible career for them.

\section{Conclusions}

The inclusion of the gender perspective in the analysis of the way politics functions reveals the many barriers imposed to women and the possible paths towards an equal access to politics and public affairs. Women are perceived as unconnected with politics and public affairs, since they demand time and dedication women supposedly cannot control by themselves due to their domestic responsibilities and current or potential activities as care givers. The capacity of negotiation of powers and defence of interests needed in the political practice is not a female talent, since women are seen as physically, intellectually, and emotionally weaker than men, having less training and capacities -and less time to get them. Feminist theorists started to explore the nature of this division of roles, bringing into light that, in Phillips' words, 'men and women are not equally autonomous and free' (Phillips, 1991: 30), and that 'inequalities in marriage and household make a nonsense of equal political rights' (Ibid.: 30-31).

Equal participation of women in politics is understood as an aim of true democratic systems intending to leave behind discrimination, exclusion, injustice, and oppression; systems in search for better models of society that reflect the real composition of the population in a more balanced way, and that look for delimiting the powers and privileges that are only in the hands of hegemonic identities. Now the question arises will the sole inclusion of women by itself make a difference in the political ma- 
chinery? Phillips states that it cannot be said that women change politics and introduce gender equity merely by being part of the political machinery. They still represent their political parties and ideologies which do not necessarily work on gender demands, equality, and policies for women. For Phillips, women's legitimacy derives from election, not nature (Ibid.: 75), she thinks that to trust that women will act in a different way than men as politicians is to give 'tremendous power to nature (or gender differentiation in the social structure) to assume that they will do what I would do in their place' (Ibid.: 76). Politics implies negotiation and argumentation that need gender awareness, training on gender issues, and a gender perspective approach.

The only idea of including women in politics may not by itself produce a change in the political practice or may not imply by itself the inclusion of the gender perspective in public policies. However, women's political underrepresentation needs to be corrected as a main goal. Low women's political participation continues to remind us that there is a problem in the whole political machinery -from theory to practice. It is complex to properly evaluate if women did or did not produce a significant change to politics and democracy by their mere inclusion at this stage of the democratisation processes, when women's political participation continues to be lower than any expected average in relation to men's. There are still too many and significant political impediments coming from the political system and from the foundations of political theory that tell women that they are not interested in politics and that they do not need to because they have been historically focused on the private matters, and because they are not as self confident as men to deal with the highly rational business of politics. Moreover, there is no consensus at all about the necessity of including women in politics among the different political systems, and about the appropriateness of legal policies that would facilitate their way into political power. Politics is still a masculine fraternal pact, and it is imperious to look for, apply, and legislate on the most effective ways to bring 
women into this race, to begin with a long-term political project such as the change of cultural perceptions through gender awareness. Political equality needs policies that produce changes in socio-economic relations and that promote parity in the different sectors of society, but it needs fundamentally straight and clear policies that guarantee women's inclusion and fair participation in the political machinery. Different institutions can contribute to their implementation in various ways and show good will by designing their own mechanisms for gender parity, but it is the democratic State the primary institution that must legislate on a national mechanism that guarantees political equality between women and men.

\section{Bibliography}

Benhabib, Seyla (1989): 'Liberal dialogue versus a critical theory of discursive legitimation', in Nancy Rosenblum (Ed.): Liberalism and the moral life, Cambridge, Harvard University Press.

Dietz, Mary (1992): 'Context is all: feminism and theories of citizenship,' in Chantal Mouffe (Ed): Dimensions of radical democracy, pluralism, citizenship, community, London, Verso.

Dietz, Mary (1994): “"The slow boring of hard boards": methodical thinking and the work of politics', The American Political Science Review, vol. 88, nº 4, (pp. 873-886).

Dworkin, Ronald (1985): 'Bakke's case: are quotas unfair?', in A matter of principle, London, Harvard University Press.

Dworkin, Ronald (1977): 'Reverse discrimination', in Taking rights seriously, Cambridge, Harvard University Press.

Dworkin, Ronald (1985): 'What did Bakke really decide?', in A matter of principle, London, Harvard University Press.

Inglehart Ronald and Norris Pippa (2001): 'Cultural obstacles to equal representation', Journal of Democracy 12:3, pp. 126-140.

Inglehart Ronald, Norris Pippa, and Welzel Christian (2003): 'Gender equality and democracy' Comparative Sociology, 1(3-4) (pp. 321-346). 
Kunovich Sheri and Paxton Pamela (2003): 'Women's political representation: the importance of ideology,' Social Forces 82:1 (pp. 87-113).

Mouffe, Chantal (1993): The return of the political, London, Verso.

Norris, Pippa (2006): 'The impact of electoral reform on women's participation,' Special Issue of Acta Politica, 41, (pp.197-213).

Pateman, Carole (1989): The disorder of women, Cambridge, Polity Press.

Phillips, Anne (1995): 'Democracy and difference', in Will Kymlicka (Ed): The rights of minority cultures, Oxford, Oxford University Press.

Phillips, Anne (1991): Engendering democracy, UK, Polity Press.

Young, Iris M. (2002): Inclusion and democracy, Oxford, Oxford University Press.

Young, Iris M. (1990): Justice and the politics of difference, Chichester, West Sussex, Princeton University Press.

Young, Iris M. (1995): 'Together in difference: transforming the logic of group political conflict', in Will Kymlicka (Ed): The rights of minority cultures, Oxford, Oxford University Press. 